Al-Azhar Bull. Sci. Vol. 19, No. 1 (June): pp. 53-67, 2008.

\title{
IDENTIFICATION OF SOME BACILLUS ISOLATES PRODUCING EXO- ENZYMES USING QUANTITATIVE REAL-TIME POLYMERASE CHAIN REACTION (PCR)
}

MAKKY, E.A.; MUHARRAM, M.M. AND BAYOUMI, R.A.

Botany \& Microbiology Dept., Faculty of Science (Boys), Al-Azhar University, Nasr City, P.N.Box.: 11884, Cairo, Egypt.

\begin{abstract}
The basic goal of this study is the isolation of some Bacillus isolates from different sources for production of bioactive products such as detection of cellulose(s) and pectinase(s) and identification of these isolates using quantitative real-time PCR (qRT PCR) depending on 16S rRNA gene in each isolate. Nine, six and two isolates were obtained from municipal sewage water, composted rice straw and expired pharmaceutical drugs (Capozide), respectively. Out of nine isolates, only four Bacilli (SW2, SW3, SW6 and SW9) were selected and examined for cellulose(s) and pectinase(s) production, and revealed that only SW2 and SW9 exhibited maximum pectate lyase (PL) and polygalacturonase (PGase) viz. 465.55 and 222.53 (U/mg), respectively. Out of six Bacilli isolates (RS1, RS3 and RS5), only RS3 showed maximum productivity of carboxymethylcellulase (CMCase) viz. 657.21 (U/mg). On the other hand, only one Bacillus isolate out of two was selected ECC2 and exhibited the maximum Avicelase productivity viz. 533.32 (U/mg). TaqMan qRT PCR method was used to detect and quantify the 16S rRNA genes of Bacillus isolates tested. Forward primer Bsub5 F and the reverse primer Bsub3 $\mathrm{R}$ were used for the amplification of 16S rRNA of the "Bacillus subtilis group", it is also successful to demonstrate the most similarities of the Bacillus isolates in this study and they are closely related to "Bacillus subtilis group".
\end{abstract}

Keywords: Polygalacturonase, Pectin Lyase, Avicelase, Carboxymethylcellulase, Quantitative Real-Time PCR.

\section{Introduction}

REAL-TIME POLYMERASE CHAIN REACTION (PCR) is based on the revolutionary method of PCR, developed by Kary Mullis in the 1980s, which allows researchers to amplify specific pieces of DNA more than a billion-fold (Mullis, 1990; Mullis and Faloona, 1987; Saiki et al., 1985). Real -time PCR represents yet another technological leap forward that has opened up new and powerful applications for researchers throughout the world (Valasek and Repa, 2005). Higuchi et al., (1992); Higuchi et al., (1993) at Roche Molecular Systems and Chiron accomplished the first demonstration of real-time PCR. By including a common fluorescent dye called ethidium bromide $(\mathrm{EtBr})$ in the PCR and running the reaction under ultraviolet light, which causes EtBr to fluoresce, they could visualize and record the accumulation of DNA with a video camera. 
The basic goal of real-time PCR is to precisely distinguish and measure specific nucleic acid sequences in a sample even if there is only a very small quantity. Realtime PCR amplifies a specific target sequence in a sample then monitors the amplification progress using fluorescent technology. During amplification, how quickly the fluorescent signal reaches a threshold level correlates with the amount of original target sequence, thereby enabling quantification (Valasek and Repa, 2005).

Recent applications of molecular techniques using 16S rRNA genes to environmental samples have shown the remarkable possibility of studying microbial populations in the absence of culturing (Akarsubasi et al., 2005; Boon et al., 2002; Godon et al., 1997; Leclerc et al., 2004; Sekiguchi et al., 1998).

A real-time quantitative PCR (QPCR) technique (Heid et al., 1996) using a fluorogenic probe allows rapid detection and quantification of various environmental microorganisms (Beller et al., 2002; Harms et al., 2003; Lebuhn et al., 2003; Yu et al., 2005). The QPCR assay with TaqMan system is highly specific and sensitive due to the use of three oligonucleotide sequences (i.e. two primers, a forward and reverse, and a fluorescent probe) complementary to the target DNA, and can be used for a large number of samples because of the advantages of PCR (Harms et al., 2003). For subsequent discussions, a "primer and probe set" denotes the three oligonucleotides of two primers, a forward and reverse, and a dually labeled fluorescent TaqMan probe (Livak et al., 1995).

Microorganisms mediate decomposition by utilization a wide variety of organic compounds under diverse environmental conditions, extracting energy from organic compounds by fermentation, anaerobic and aerobic respiration (Cunha-Santino and Bianchini, 2007). Microbial microorganisms release enzymes into the surrounding environment in order to degrade macromolecular and insoluble organic matter prior to cell uptake and metabolism (Chróst, 1990).

Cellulose is the world's most abundant natural biopolymer and a potentially important source for the production of industrially useful materials such as fuels and chemicals. Enzymatic hydrolysis is an economic process in the conversion of cellulose to easily fermentable low cost sugars (Muthuvelayudham and Viruthagiri, 2006). Cellulase was identified as one of the key enzyme degrading cellulose (Kotchoni et al., 2003). A cellulosic enzyme system consists of three major components: exo-1,4- $\beta$-D-glucan cellobiohydrolases, which cleave cellobiosyl units from the ends of cellulose chains; endo-1,4- $\beta$-D-glucases which cleave internal glucosidic bonds and 1,4- $\beta$-D-glucosidase, which cleaves glucose units from 
cellooligosaccharides (Jorgensen et al., 2003; Muthuvelayudham and Viruthagiri, 2006). Cellulose activities have seen in many nitrogen fixing bacteria such as Sinorhizobium fredii (Chen et al., 2004; and Mateos et al., 1992), Bacillus spharricus (Singh et al., 2004), Bacillus circulans (Baird et al., 1990), Paenibacillus azotofixans (Rosado et al., 1998). Although with the change of Bacillus classification, all nitrogen-fixing Bacillus strains Bacillus polymyxa, Bacillus macerans, Bacillus azotofixans are now assigned to Paenibacillus (Rosado et al., 1998; Gorska et al.,2001; Hossain et al.,1999; Kashem et al., 2004; Mawadza et al., 2000; Shawky, 1983; Krieg and Holt, 1984).

Pectinases are enzymatic biocomposites widely used in the industries because of their capacity to degrade pectic substances as fiber deguming (Baracat et al., 1989), citric fruit peeling, industrial residues from the process of coffe, cocoa, tobacco, tea (Martins et al., 2002), wine clarification, juice extraction, fruit and pectin hydrolyses (Kashyap et al., 2003). Pectinase synthesis occurs in many microbial groups, however, for the industrial Pectinase production, fungi are the most used group due to their high enzymatic excretion capacity (Solis et al., 1990). Pectinolytic enzymes are classified according to their way of attack on the galacturonan part of the pectin molecule. They can be distinguished between pectin methylesterases (EC 3.1.11.1) that deesterify pectins to low methoxyl pectins or pectic acid, and pectin depolymerases, which split the glycosidic linkages between galacturonosyl (methyl ester) residues. Polygalacturonases split glycosidic linkage next to free carboxyl groups by hydrolysis while pectate lyase split glycosidic linkages next to free carboxyl groups by $\beta$-elimination. Both endo types of PGs and PALs (EC 3.2.1.15 and EC 4.2.2.2, respectively) are known by splitting randomly the pectin chain.

Exo-PGs (EC 3.2.1.67) release monomers or dimmers from the non-reducing end of the chain, whereas exo-PALs (EC 4.2.2.9) release unsaturated dimmers from the reducing end. Highly methylated pectins are degraded by endo-pectin lyases (PL; EC 4.2.2.10) and also by a combination of PE with PG or PAL (Sarkanen, 1991; Pilnik and Voragen, 1993; Martin et al., 2004).

\section{Materials And Methods}

All chemicals used were of analytical grade. Dinitrosalicylic acid (DNS), pectin, polygalacturonic acid (PGA), carboxymethylcellulose (CMC), Avicel was obtained from Sigma Chemical Co., USA. 
Sampling collection: Samples were collected from different sources such as sewage water (Jeonnong-dong, Dongdaemun-gu, Seoul, Korea), rice straw (ElBohira governorate, Egypt) and household disposal expired pharmaceuticals (expired Capozide compound), this hazard expired pharmaceutical only $0.1 \mathrm{~g} / 100 \mathrm{ml}$ was dispersed in distilled water then filtered using $0.45 \mu \mathrm{m}$ GHP cellulose acetate (Hydrophilic).

Cultivation: Serial dilutions for various purposes, particularly for estimation of the numbers of viable bacteria in a sample, and it is of obvious benefit to be able to assess the uncertainty at any step of such a series and to be able to construct confidence intervals (CLs) both for the dilution and for any count based on them (Hedges, 2002). The serial dilutions of samples were prepared to obtain "colony forming unit" (CFU) by pipetting $1 \mathrm{ml}$ of sample to a tube containing $9 \mathrm{ml}$ distilled water to obtain $10^{-1}$ dilution tube then vortex to mix completely, repeat and continue serial dilution until $10^{-9}$ dilution tube. Transfer $0.1 \mathrm{ml}$ dilution to each of three agar plates containing nutrient agar media (Difco ${ }^{\mathrm{TM}}$ ) (Atlas, 2005) and distribute evenly with Drigalski spatula. The agar plates were incubated upside down at $37^{\circ} \mathrm{C}$ for $1-3$ days. The plates with 30-300 colonies were counted and CFU in each plate was calculated. Proteins were estimated by the method of (Bradford, 1976) using bovine serum albumin as a standard.

\section{Polygalacturonase (EC 3.2.1.15) activity}

Polygalacturonase (PGase) (EC 3.2.1.15) activity was assayed by the colorimetric method. Briefly, $100 \mu \mathrm{l}$ of suitably diluted cell-free supernatant was incubated with $100 \mu \mathrm{l}$ of substrate (PGA, $1.0 \%$, w/v) at $40^{\circ} \mathrm{C}$ for $10 \mathrm{~min}$ under static conditions. Reducing sugar was determined using 3,5-dinitrosalicylic acid (DNS) reagent (Ghose, 1987 ; Thygesen et al., 2003), the substrate $(900 \mu l)$ was equilibrated at $50^{\circ} \mathrm{C}, 100 \mu \mathrm{l}$ sample was added and after $10 \mathrm{~min} 1500 \mu \mathrm{l}$ DNS reagent was added. Mixture was finally diluted to $5 \mathrm{ml}$ with deionized water $(4.4 \mathrm{ml})$. The absorbance of the color developed was measured at $530 \mathrm{~nm}$. For the standards, $100 \mu 1$ glucose $(2.5-$ $10 \mathrm{mM}$ ) was added to $900 \mu \mathrm{l}$ substrate and $1500 \mu \mathrm{l}$ DNS reagent (Thygesen et al., 2003). The samples and standards were boiled $\left(100^{\circ} \mathrm{C}\right)$ for $5 \mathrm{~min}$ and cooled on ice. One unit of enzyme was defined as the amount of enzyme which catalyses the formation of $1 \mu \mathrm{mol}$ of galacturonic acid/min at fixed $\mathrm{pH}$.

Pectin Lyase (EC 4.2.2.10) activity

Pectin Lyase (PL) (EC 4.2.2.10) activity of the given samples was assayed by the method of (Pitt, 1988), modified by (Kashyap et al., 2000). Briefly, 1ml of suitably 
diluted enzyme sample was added to $5.0 \mathrm{ml}$ of pectin solution $(1 \% \mathrm{w} / \mathrm{v})$. The volume of the test samples was adjusted to $10 \mathrm{ml}$ with distilled water. The samples were incubated at $40^{\circ} \mathrm{C}$ for $2 \mathrm{hr}$. This was followed by the addition of zinc sulphate $(0.6 \mathrm{ml}$, $9.0 \% \mathrm{w} / \mathrm{v})$ and sodium hydroxide $(0.6 \mathrm{ml}, 0.5 \mathrm{M})$. The samples were centrifuged (3000 xg, $10 \mathrm{~min}$ ) and $5.0 \mathrm{ml}$ of the clear supernatant was added to a mixture of thiobarbituric acid $(3.0 \mathrm{ml}, 0.04 \mathrm{M}), \mathrm{HCl}(2.5 \mathrm{ml}, 0.1 \mathrm{M})$ and distilled water $(0.5 \mathrm{ml})$. The mixture was heated in a boiling water bath for $30 \mathrm{~min}$, cooled to room temperature and the absorbance of the colored solution was measured at $550 \mathrm{~nm}$. One unit of enzyme activity was defined as the amount of enzyme that caused a change in absorbance of 0.01 under the condition of the assay.

\section{Avicelase (EC 3.2.1.91) activity}

Avicelase (EC 3.2.1.91) activity was assayed by incubation for $24 \mathrm{~h}$ at $80^{\circ} \mathrm{C}$ in a shaking incubator. Reaction mixture $(1 \mathrm{ml})$ contained a $1 \%(\mathrm{w} / \mathrm{v})$ suspension of microcrystalline cellulose (Avicel) in (0.1M) Na-succinate $\mathrm{pH}$ 6.0. After removal of solids by centrifugation, aliquots of the supernatants were assayed for the release of reducing sugars. One unit of enzyme corresponds to the release of $1 \mu \mathrm{mol}$ of glucose equivalent per minute (Bronnenmeier and Staudenbauer, 1990).

Carboxymethylcellulase (EC 3.2.1.4) activity

Carboxymethylcellulase (CMCase) (EC 3.2.1.4) activity was assayed by incubation for $60 \mathrm{~min}$ at $80^{\circ} \mathrm{C}$ in a $0.5 \%(\mathrm{w} / \mathrm{v})$ solution of carboxymethylcellulose $(\mathrm{CMC})$ in $(0.1 \mathrm{M}) \mathrm{Na}$-succinate, at $\mathrm{pH}$ 6.0. Enzyme and reagent blanks were also simultaneously incubated with the test samples, and the rate of production of reducing sugar was determined. One international unit (IU) of enzyme activity was defined as the amount of enzyme releasing $1 \mu$ mol reducing sugar from CMC per minute using glucose as standard.

\section{Isolation of DNA Extraction from Bacterial Cultures}

DNA extraction was isolated from bacterial isolates using (Genomic DNA from Tissue, User Manual, NucleoSpin ${ }^{\circledR}$ Tissue, April 2007/Rev. 06, MACHEREYANGEL GmbH \& Co. KG, Germany). The DNA was checked on $1.5 \%$ agarose gels and measured by photometry at 260 and $280 \mathrm{~nm}$ (Stephan et al., 2004).

\section{Primer design for Real-Time PCR}

The primers used in this study hybridize to conserved regions on the $16 \mathrm{~S}$ rRNA gene. The forward primer Bsub5 F (5`-AAGTCGAGCGGACAGATGG -3`) and the 
reverse primer Bsub3 R (5 -CCAGTTTCCAATGACCCTCCCC -3`) were used for the qRT-PCR amplification of a 595-bp fragment corresponding to an internal protein of the "bacillus subtilis group" 16S rRNA. TaqMan polymerase was used with the buffer supplied by the manufacturer, with a final primer concentration of $0.4 \mu \mathrm{M}$ (Wattiau et al., 2001).

\section{Real-Time PCR}

Amplification and detection were carried out in 48-well optical plates on MJ Mini (BIO-RAD) personal thermal cycler, with TaqMan Universal PCR 2x master mix (Applied Biosystem), a $0.4 \mu \mathrm{M}$ concentration of each primer, a $0.2 \mu \mathrm{M}$ concentration of each probe and 1 to $2 \mathrm{ng}$ of sample DNA in a final volume of $20 \mu \mathrm{l}$ per reaction. The whole $16 \mathrm{~S}$ rDNA sequence was amplified for quantitative PCR with incubation at $95^{\circ} \mathrm{C}$ for $3 \mathrm{~min}$ and a hold of $95^{\circ} \mathrm{C}$ for $15 \mathrm{sec}$ to activate DNA polymerase (TaqMan polymerase) and annealing incubation at $60^{\circ} \mathrm{C}$ for $1 \mathrm{~min}$, followed by 45 cycles of $95^{\circ} \mathrm{C}$ for $15 \mathrm{sec}$, and $30^{\circ} \mathrm{C}$ for $1 \mathrm{~min}$. The specific fluorescent probe was labeled at the 5 , end with the reporter dye 6carboxyfluorescin (FAM).

\section{Results and Discussion}

At the end of incubation time the bacterial counts of CFU were differ according to the source of samples Table (1). All the samples plates were counted and stained using Gram reaction to select only the bacilli organisms obtained according to the primer specification used in our study also for determine the isolate characterization. Only four bacilli isolates out of nine were selected from sewage water samples after $24 \mathrm{~h}$ incubation period. Three isolates out of six and only one out of two isolates were selected from rice straw and expired Capozide compound samples respectively Table (2).

Table (1): Determination of CFU and bacterial count of isolates from three sources.

\begin{tabular}{ccc}
\hline Source of sample & $\begin{array}{c}\text { CFU* } \\
\mathbf{( 1 0} \text { /ml) }\end{array}$ & $\begin{array}{c}\text { Incubation } \\
\text { period (h) }\end{array}$ \\
\hline Sewage water & 16.33 & 24 \\
\hline Rice straw & 21.00 & 48 \\
\hline $\begin{array}{c}\text { Expired Capozide } \\
\text { compound }\end{array}$ & 8.33 & 72 \\
\hline
\end{tabular}

* Colony forming unit. 
The bacterial isolated from various sources were screened for pectinases and cellulases enzymes productivity as industrially important by-products by these bacilli using spectrophotometric assay methods. As it is shown in Table (3), SW9 isolate had maximum PGase enzyme specific activity $222.53 \mathrm{IU} / \mathrm{mg}$, maximum pectin lyase specific activity $465.55 \mathrm{IU} / \mathrm{mg}$ was observed by SW2 isolate. However, at ECC2 and RS3 isolates exhibited the maximum Avicelase and CMCase specific activities $533.32 \mathrm{IU} / \mathrm{mg}$ and $657.21 \mathrm{IU} / \mathrm{mg}$, respectively. On the other hand, Emtiazi et al., (2007) showed that Paenibacillus strain E was isolated from soil and exhibited CMCase $4 \mathrm{Uml}^{-1}$ when it was grown on $\mathrm{CMC}$ as the only sources of carbon.

Table (2): Characterization of bacterial isolates and symbols.

\begin{tabular}{ccc}
\hline Type of sample & $\begin{array}{c}\text { Isolate } \\
\text { symbol }\end{array}$ & $\begin{array}{c}\text { Isolate } \\
\text { characterization }\end{array}$ \\
\hline & SW1 & G- ${ }^{\text {, }}$, cocci \\
& SW2 & G+ ${ }^{2}$, rods \\
Sewage water & SW3 & G+, rods, ENS ${ }^{3}$ \\
& SW4 & G+, cocci \\
& SW5 & G-, cocci \\
& SW6 & G+, rods \\
& SW7 & G-, cocci \\
& SW8 & G-, cocci \\
& SW9 & G+, rods, ENS \\
\hline & RS1 & G+, rods, ENS \\
Rice straw & RS2 & G-, cocci \\
& RS3 & G+, rods \\
& RS4 & G-, cocci \\
& RS5 & G+, rods \\
& RS6 & G-, cocci \\
\hline Expired & & G+, cocci \\
Capozide & ECC1 & G+, rods \\
\hline
\end{tabular}

${ }^{1}$ : Gram negative; ${ }^{2}$ : Gram positive; ${ }^{3}$ : Endo-spore former.

According to large multiple of Bacillus 16S rRNA sequences, it was noticed that group-specific consensus motifs were present in the variable domains I and II. Two PCR primers, Bsub5 F and Bsub3 R, were chosen that were predicted to specifically amplify a 595-bp DNA fragment of the "Bacillus subtilis group" 16S rRNA (Wattian et al., 2001). These primers respectively encompassed nucleotides 59-79 (variable domain I) and 625-646 (variable domain II) relative to the E. coli $16 \mathrm{~S}$ rRNA numbering. Nucleotide database comparisons using BLASTN (Altschul et al., 1998). Given the considerable number of Bacillus species established to date, our 
choice was restricted to species that were representative of the different Bacillus groups (Ash et al., 1991) or that were seen to be either identical or very similar in the $16 \mathrm{~S}$ rRNA multiple alignment.

Table (3): Production of pectinase(s) and cellulase(s) by selected bacterial isolates.

\begin{tabular}{|c|c|c|c|c|c|c|c|c|c|c|c|c|}
\hline \multirow[b]{2}{*}{$\begin{array}{l}\text { Source \& } \\
\text { symbol of } \\
\text { isolate }\end{array}$} & \multicolumn{3}{|c|}{ PGase assay } & \multicolumn{3}{|c|}{ PL assay } & \multicolumn{3}{|c|}{ Avicelase assay } & \multicolumn{3}{|c|}{ CMCase assay } \\
\hline & $\begin{array}{c}\text { Total } \\
\text { activity } \\
\text { (IU/ml) }\end{array}$ & $\begin{array}{l}\text { Protein } \\
\text { content } \\
(\mathrm{mg} / \mathrm{ml})\end{array}$ & $\begin{array}{l}\text { Sp. act. } \\
\text { (IU/mg) }\end{array}$ & $\begin{array}{c}\text { Total } \\
\text { activity } \\
\text { (IU/ml) }\end{array}$ & $\begin{array}{l}\text { Protein } \\
\text { content } \\
(\mathrm{mg} / \mathrm{ml})\end{array}$ & $\begin{array}{l}\text { Sp. act. } \\
\text { (IU/mg) }\end{array}$ & $\begin{array}{c}\text { Total } \\
\text { activity } \\
\text { (IU/ml) }\end{array}$ & $\begin{array}{l}\text { Protein } \\
\text { content } \\
(\mathrm{mg} / \mathrm{ml})\end{array}$ & $\begin{array}{l}\text { Sp. act. } \\
\text { (IU/mg) }\end{array}$ & $\begin{array}{c}\text { Total } \\
\text { activity } \\
\text { (IU/ml) }\end{array}$ & $\begin{array}{l}\text { Protein } \\
\text { content } \\
(\mathrm{mg} / \mathrm{ml})\end{array}$ & $\begin{array}{l}\text { Sp. act. } \\
\text { (IU/mg) }\end{array}$ \\
\hline SW2 & 284.61 & 1.4 & 203.29 & 512.11 & 1.1 & 465.55 & 350.01 & 1.9 & 184.21 & 460.36 & 1.1 & 418.51 \\
\hline SW3 & 340.10 & 4.2 & 80.97 & 399.22 & 1.4 & 285.16 & 390.22 & 1.8 & 216.79 & 566.61 & 0.96 & 590.22 \\
\hline \multicolumn{13}{|l|}{ Rice straw } \\
\hline RS1 & 270.11 & 1.3 & 207.78 & 408.12 & 1.9 & 214.74 & 492.99 & 1.0 & 492.99 & 421.62 & 1.4 & 301.16 \\
\hline RS3 & 320.21 & 3.2 & 100.06 & 320.21 & 2.2 & 145.55 & 510.20 & 1.2 & 425.17 & 611.21 & 0.93 & 657.21 \\
\hline RS5 & 280.39 & 1.4 & 200.28 & 500.31 & 1.3 & 384.58 & 503.31 & 1.4 & 359.51 & 365.50 & 1.1 & 332.27 \\
\hline \multicolumn{13}{|l|}{$\begin{array}{c}\text { Expired } \\
\text { Capozide } \\
\text { compound }\end{array}$} \\
\hline $\mathrm{ECC} 2$ & 103.33 & 2.3 & 44.93 & 109.21 & 2.4 & 45.50 & 533.32 & 1.0 & 533.32 & 375.67 & 2.2 & 170.76 \\
\hline
\end{tabular}

The two PCR primers, Bsub5 $\mathrm{F}$ and Bsub3 $\mathrm{R}$ and the probe TaqMan polymerase were highly specific for the target group of microorganisms and did not detect a control without DNA template. For SW2, SW3 and SW6 isolates as shown in Table (4), were successfully amplified and closely identical for the Bacillus strains Bacillus atrophaeus, Bacillus pumilus and Bacillus licheniformis respectively. However, RS1 and RS3 isolates in this study were amplified and closely related to Bacillus amyloliquefaciens and Bacillus subtilis respectively. On the other hand, SW9, RS5 and ECC2 isolates were not amplified using RT-PCR and not closely related to any of Bacillus subtilis group and the primers were not specific for the target group of these Bacillus isolates.

Bacillus isolates and qRT-PCR were generated by adding PCR primers specific for Bacillus subtilis group and running a RT-PCR reaction. Cycle threshold indicates the cycle at which the fluorescence detected by the instrument passed a predetermined threshold, indicating the presence of a PCR product. Melting temperature $(\mathrm{Tm})$ is the temperature at which the amplified DNA double helix denatured into single strands. This is sequence specific. The isolate samples in this study and tested for quantification real-time PCR were have approximately the same melting point of Bacillus subtilis group except SW9, RS5 and ECC2 isolates were not determined any similarities related to Bacillus cereus, Bacillus circulans and 
paenibacillus polymyxa strains Table (4). Results of the standard curve and Bacillus subtilis group strains of template DNA primer and probe were shown in Table (5).

Table (4): Similarities of Bacillus strains closely related to our isolates in the comparative quantification RT-PCR.

\begin{tabular}{clcc}
\hline $\begin{array}{c}\text { Isolate } \\
\text { symbol }\end{array}$ & \multicolumn{1}{c}{ Closely related strain } & Strain No. & $\begin{array}{c}\text { Amplification } \\
\text { RT-PCR }\end{array}$ \\
\hline SW2 & Bacillus atrophaeus & ATCC 49337T* & + \\
SW3 & Bacillus pumilus & ATCC 7061T & + \\
SW6 & Bacillus licheniformis & ATCC 14580T & + \\
& Bacillus cereus & bc 1 & - \\
\hline RS1 & Bacillus amyloliquefaciens & ATCC 23350T & + \\
RS3 & Bacillus subtilis & bs1 & + \\
& Bacillus circulans & ATCC 4513T & - \\
& paenibacillus polymyxa & ATCC 842T & - \\
RS5 & NA & - & - \\
SW9 & NA & - & - \\
ECC2 & NA & - & - \\
\hline
\end{tabular}

+ : Sign indicates that the "B. subtilis group" amplification RT-PCR was positive.

-: Sign indicates that the "B. subtilis group" amplification RT-PCR was negative.

NA: Not amplified.

The technique of quantitative real-time PCR has emerged recently, owing to the advanced development of fluorogenic chemistry, as an effective means for the detection and quantification of microorganisms at very low concentrations. Comparing with the conventional hybridization and PCR based techniques; qRTPCR not only has better sensitivity and reproducibility, but also is quicker to perform and has a minimum risk of amplicon carry-over contamination (Fang and, Zhang 2006).

To facilitate global quantification of Bacillus isolates and normalization to a single standard curve of total bacteria in this study, a pair of primers binding to highly conserved regions on the $16 \mathrm{~S}$ rRNA gene were used to amplify the fulllength 16S rRNA. Amplification of the whole $16 \mathrm{~S}$ gene is necessary because the regions to identify and define the different bacterial species or groups are distributed over the full length of the $16 \mathrm{~S}$ rRNA sequence. Contamination of TaqMan polymerase with bacterial genomic DNA that is not removed during the purification process is considered a serious problem with use of real-time PCR for bacterial quantification (Stephan et al., 2004). Contamination usually occurs in last cycles of real-time PCR (after 40 cycles). To circumvent the problem, some authors 
recommend treating Taq polymerase with DNase I to reduce contamination (Lyons et al., 2000; and Nadkarni et al., 2002).

Table (5): Standard curve results and "B. subtilis group" strains of template DNA primers and probe.

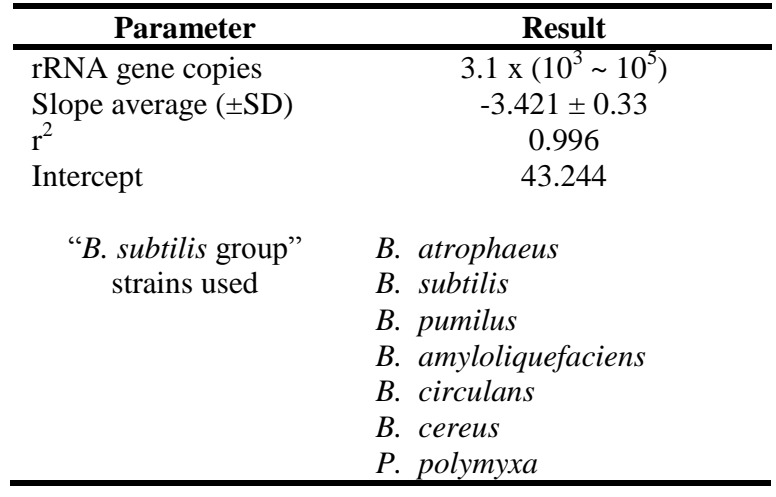

\section{References}

1. Akarsubasi A.T.; Ince O.; Kirdar B.; Oz N.A.; Orhon D.; Curtis T.P.; Head I.M.; Ince B.K., (2005): Effect of wastewater composition on archaeal population diversity. Water Res 39 (8): 1576-1584.

2. Altschul S.; Madden T.; Schaffer A.; Zhang J.H.; Zhang Z.; Miller W.; and Lipman D., (1998): Gapped BLAST and PSI-BLAST: a new generation of protein database search programs. FASEB J 12: 102.

3. Ash C.; Farrow J.A.; Wallbanks S.; and Collins M.D., (1991): Phylogenetic heterogeneity of the genus Bacillus revealed by comparative analysis of small subunit ribosomal RNA sequences. Lett Appl Microbiol 13: 202-206.

4. Atlas R.M. 2005: Handbook of Media for Environmental Microbiology. Published 2005, second edition.

5. Baird D.S.; Johnson D.A.; and Seligy V.L., (1990): Molecular cloning, expression and characterization of endo- $\beta-1,4$-glucanase genes from Bacillus polymyxa and Bacillus circulans. J Bacteriol., 172: 1576-1586.

6. Baracat M.C.; Valentti M.C.; Muchovej J.J.; Araujo E.F.; Silva D.O., (1989): Selection of Pectinolytic fungi for deguming of natural fibers. Biotechnol Lett 11, 799-802.

7. Beller H.R.; Kane S.R.; Legler T.C.; Alvarez P.J.J., (2002): A real-time polymerase chain reaction method for monitoring anaerobic, hydrocarbon-degrading bacteria based on a catabolic gene. Environ Sci Technol 36(18): 3977-3984. 
8. Boon N.; De Windt W.; Verstraete W.; Top E.M., (2002): Evaluation of nested PCRDGGE (denaturing gradient gel electrophoresis) with group-specific 16S rRNA primers for the analysis of bacterial communities from different wastewater treatment plants. FEMS Microbiol Ecol 26: 101-112.

9. Bradford M. 1976: A rapid and sensitive method for the quantification of microgram quantities of protein using the principle of protein-dye binding. Anal Biochem; 72: 24854 .

10. Bronnenmeier, K. and staudenbauer, W.L. 1990: Cellulose hydrolysis by a highly thermostable endo-1,4- $\beta$-glucanase (Avicelase I) from Clostridium stercorarium. Enzyme Microb. Technol. 12, 431-436.

11. Chen P.J.; Wei T.C.; Chang Y.T.; and Lin L.P, (2004): Purification and characterization of carboxymethyl cellulase from Sinorhizobium fredii. Bot Bull Acad Sin., 45: 111-118.

12. Chróst R.J., (1990): Microbial ectoenzymes in aquatic environments. In: Overbeck, J., Chróst, R.J. (eds). Aquatic microbial ecology: biochemical and molecular approaches. Springer-Verlag, New York, USA, p. 47-78.

13. Cunha-Santino M.B.; and Bianchini Jr.I. (2007): Cellulase activities during decomposition of a submerged aquatic macrophyte (Utricularia breviscapa): A microcosm assay. Brazilian Journal of Microbiology, 38: 230-236.

14. Emtiazi G.; Pooyan M.; and Shamalnasab M., (2007): Cellulase activities in nitrogen fixing Paenibacillus isolates from soil in N-free media. World Journal of Agricultural Sciences 3 (5): 602-608.

15. Fang H.H.P. and Zhang T., (2006): Acidophilic hydrogen production from rice slurry. Int. J. Hydrogen Energy. 31, 683-692.

16. Ghose T. K., 1987: Measurement of cellulase activities. Pure Appl Chem; 59: 257-68.

17. Godon J.J.; Zumstein E.; Davert P.; Habouzit F.; Moletta R., (1997): Molecular microbial diversity of an anaerobic digestor as determined by small subunit rRNA sequence analysis. Appl Environ Microbiol 63(7): 2802-2813.

18. Gorska E.; Tudek B.; and Russel S., (2001): Degradation of cellulose by nitrogen-fixing strain of Bacillus polymyxa. J Acta Microbiol Pol., 50: 129-137.

19. Harms G.; Layton A.C.; Dionisi H.M.; Gregory I.R.; Garrett V.M.; Hawkins S.A.; Robinson K.G.; Sayler G.S., (2003): Real-time PCR quantification of nitrifying bacteria in a municipal wastewater treatment plant. Environ Sci technol 37(2): 343-351.

20. Hedges A.J. 2002: Estimating the precision of serial dilutions and viable bacterial counts. International Journal of Food Microbiology, Volume 76, Number 3, pp. 207-214.

21. Heid C.A.; Stevens J.; Livak K.J.; Williams P.M., (1996): Real-time quantitative PCR. Genome Res 6: 986-994. 
22. Higuchi R.; Dollinger G.; Walsh P.S.; and Griffith R., (1992): Simultaneous amplification and detection of specific DNA sequences. Biotechnology 10: 413-417.

23. Higuchi R.; Fockler C.; Dollinger G.; and Watson R., (1993): Kinetic PCR analysis: realtime monitoring of DNA amplification reactions. Biotechnology 11: 1026-1030.

24. Hossain F.M.M.; Rahman N.C.; and Malek M.A., (1999): Production of extracellular carboxymethyl cellulose and cellobiase by a thermophilic Bacillus sp. Bangeladesh J Microbiol., 16: 115-125.

25. Jorgensen H.; Eriksson T.; Borjesson J.; Tjerneld F.; and Olsson L., (2003): Purification and characterization of five cellulases and xylanase from Penicilliul brasilianum IBI 20888. Enzyme and Microbial Technology. 32: 851-861.

26. Kashem M.A.; Manchur M.A.; Rahman M.S.; and Anvar M.N., (2004): Effect of carbon and nitrogen sources on the production of reducing sugars, extra-cellular protein and cellulytic enzymes by two cellulolytic bacteria isolates. Pak J Biol Sci., 7: 1660-1663.

27. Kashyap D.R.; Soni S.K.; Tewari R., (2003): Enhanced production of pectinase by Bacillus sp. DT7 using solid state fermentation. Bioresour Technol 88: 251-254.

28. Kashyap, D.R.; Chandra S.; Kaul A.; and Tewari R. (2000): Production, purification and characterization of pectinase from a Bacillus sp. DT7. World Journal of Microbiology and Biotechnology 16, 277-282.

29. Kotchoni O.S.; Shonukan O.O.; and Gachomo W.E., (2003): Bacillus pumilus BPCRI 6, a promising candidate for cellulose production under conditions catabolite repression. Afr. J. Biotechnol. 2 (6): 140-146.

30. Krieg N.R.; and Holt J.G., (1984): Bergey's manual of systematic bacteriology, $1^{\text {st }}$ Edn. Williams and Wiilkins, Balimore, Md.

31. Lebuhn M.; Effenberger M.; Gronauer A.; Wilderer P.A.; Wuertz S., (2003): Using quantitative real-time PCR to determine the hygienic status of cattle manure. Water Sci Technol 48(4): 97-103.

32. Leclerc M.; Delgenes J-P.; Godon J-J., (2004): Diversity of the archaeal community in 44 anaerobic digestors as determined by single strand conformation polymorphism analysis and 16S rDNA sequencing. Environ Microbiol 6(8): 809-819.

33. Livak K.J.; Flood S.J.; Marmaro J.; Giusti W.; Deetz K., (1995): Oligonucleotides with fluorescent dyes at opposite ends provides a quenched probe system useful for detecting PCR product and nucleic acid hybridization. PCR Methods Appl 4: 357-362.

34. Lyons s.r.; Griffen A.L.; and Leys E.J., (2000): Quantitative real-time PCR for Porphyromonas gingivalis and total bacteria. J Clin Microbiol., 38: 2362-2365.

35. Martin N.; De Souza S.R.; Saliva R.D.; and Gomes E. (2004): Pectinase production by fungal strains in Solid-State Fermentation Using Agro-Industrial Bioproduct. Brazilian Archives of Biology and Technology. Vol. 47, n. 5: pp. 813-819. 
36. Martins E.S.; Silva D.; da Silva R.E.; Gomes E., (2002): Solid state production of thermostable pectinases from thermophilic Thermoascus aurantiacus. Proc. Biochem., 37: 949-954.

37. Mateos P.F.; Jimenez-Zurdo J.I.; Chen J.; Squartini A.S.; Haack S.K.; Martinez-Molina E.; Hubbell D.H.; and Dazzo F.B., (1992): Cell-associated Pectinolytic enzyme in Rhizobium leguminosarum biovar trifolii. 58: 1816-1822.

38. Mawadza C.; Hatti-Kaul R.; Zvauya R.; and Mattiasson B.O., (2000): Production and characterization of cellulases produced by two Bacillus strains. J Biotechnolo., 83: 177187.

39. Mullis K.B. and Faloona F.A., (1987): Specific synthesis of DNA in vitro via a polymerase-catalyzed chain reaction. Methods Enzymol 155: 335-350.

40. Mullis K.B., (1990): The unusual origin of the polymerase chain reaction. Sci Am 262: 56-61.

41. Muthuvelayudham R.; and Viruthagiri T., (2006): Fermentative production and kinetics of cellulose protein on Trichoderma reesei using sugarcane bagasse and rice straw. African Journal of Biotechnology. Vol. 5 (20), pp. 1873-1881.

42. Nadkarni M.A.; Martin F.E.; Jacques N.A.; and Hunter N., (2002): Determination of bacterial load by real-time PCR using a broad range (universal) probe and primers set. Microbiology 148: 257-266.

43. Pilnik W.; and Voragen A.G.J., (1993): Pectic enzymes in fruit and vegetable juice manufacture. In: Nagodawithama, T. and Reed, G. (Eds.). Enzymes in Food Processing. New York: Academic Press. Pp 363-399.

44. Pitt O., 1988: Pectic lyase from Rhoma medicabinis var. pinodella. Methods in Enzymology 161, 350-365.

45. Rosado A.S.; de Azevedo F.S.; da Cruz D.W.; van Elsas J.D.; and Seldin I., (1998): Phenotypic and genetic diversity of Paenibacillus azotofixans strains isolated from the rhizolpane or rhizosphere soil of different grasses. J Appl Microbiol., 84: 216-226.

46. Saiki R.K.; Scharf S.; Faloona F.A.; Mullis K.B.; Horn G.T.; Erlich H.A.; and Arnheim N., (1985): Enzymatic amplification of beta-globin genomic sequences and restriction site analysis for diagnosis of sickle cell anemia. Science 230: 1350-1354.

47. Sarkanen S., (1991): Enzymatic lignin degradation: an extracellular view. In: Leathem, G.F. and Himmel M.E. (Eds.). Enzymes in Biomass Conversion, ACS Symp. Series 460, American Chem Soc., pp. 247-269.

48. Sekiguchi Y.; Kamagata Y.; Syutsubo K.; Ohashi A.; Harada H.; Nakamura K., (1998): Phylogenetic diversity of mesophilic and thermophilic granular sludge determined by $16 \mathrm{~S}$ rRNA gene analysis. Microbiology 144: 2655-2665. 
49. Shawky B.T., (1983): Growth and nitrogen fixation by culture of Bacillus sp. S77g, Pseudomonas sp. S44b and Klebsiella sp. S145m, isolated from Egyption Soils. J Zentralbl Mikrobiol., 138: 9-15.

50. Singh J.; Batra N.; and Sobti R.C., (2004): Purification and characterization of alkaline cellulose produced by a novel isolate Bacillus sphaericus JS1. J Ind Microbiol Biotechnol., 31: 51-59.

51. Solis S.; Flores M.E.; Huitron C., (1990): Isolation of endopolygalacturonase hyperproducing mutants of Aspergillus sp. CH-Y-1043. Biotechnol Lett 12: 751-756.

52. Stephan J.O.; Meike M.; Uwe U.; Jochen H.; and Stephen S. 2004: Quantification of Intestinal Bacterial Populations by Real-Time PCR with a Universal Primer Set and Minor Groove Binder Probes: a Global Approach to the Enteric Flora. Journal of Clinical Microbiology, June 2004, p. 2566-2572.

53. Thygesen A.; Thomsen A.B.; Schmidt A. S.; Jǿrgensen H.; Ahring B. K.; and Olsson L. (2003): Production of cellulose and hemicellulose degrading enzymes by filamentous fungi cultivated on wet-oxidized wheat straw. Enzyme Microb Technol 32: 606-615.

54. Valasek M.A. and Repa J.J., (2005): The power of real-time PCR. Adv Physiol Educ 29: 151-159.

55. Wattiau P.; Renard M.E.; Ledent P.; Debois V.; Blackman G.; and Agathos S.N. 2001: A PCR test to identify Bacillus subtilis and closely related species and its application to the monitoring of wastewater biotreatment. Appl. Microbiol., 56:816-819.

56. Yu Y.; Lee C. Kim J.; Hwang S., (2005): Group-specific primer and probe sets to detect methanogenic communities using quantitative real-time polymerase chain reaction. Biotechnol Bioeng 89(6): 670-679. 


\title{
تعريف بعض عزلات باسيلس منتجة للإنزيمات الخارجية
}

باستخدام تفاعل كمي للبلمرة المتسلسل

\author{
عصام مكي, مجدي محمد محرم , رضا احمد بيومي \\ قسم النبات والميكروييولوجى -كلية العلوم(بنين)-جامعة الأزهـر -القاهرة - الرقم \\ البريدي:11884.
}

الملخص العريي

الههف الرئيسي من هذه الدراسة هو تحديد بعض عزلات من باسيلس معزولة من مصادر

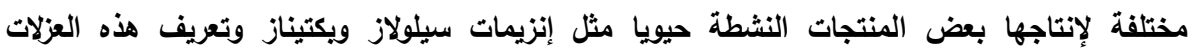

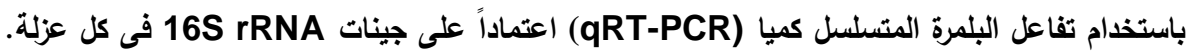
تم عزل عدد 9,6,2 عزلات من جنس باسيلس من مياه الصرف الصحي وقش الأرز المتحلل فى صورة

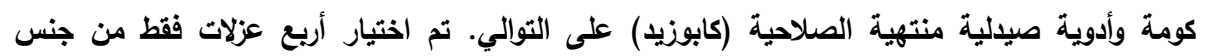

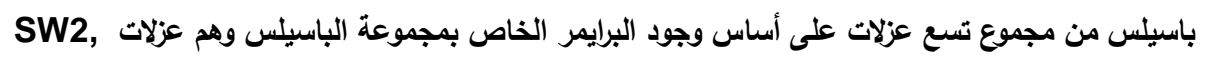
SW3, SW6,SW9 إنزيم بكتين لاياز ويولى جالاكتيرونيز 475.55 , 222.53 (وحدة /مجم) على التوالي بينما أظهرت ثثلاث

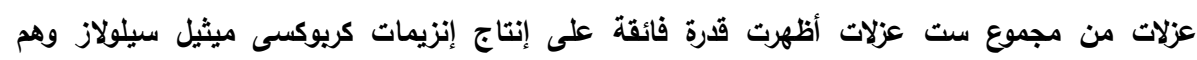

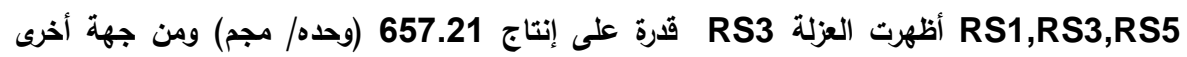
أظهرت عزلة واحدة فقط وهى ECC2 من عزلتان قدرة فائقة على إنتاج إنزيم أفيسيلاز

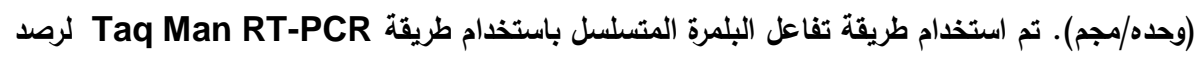
وعد وتحديد جينات 16S rRNA فى أجناس باسيلس محل الاراسة. تم استخدام بادىء أمامي

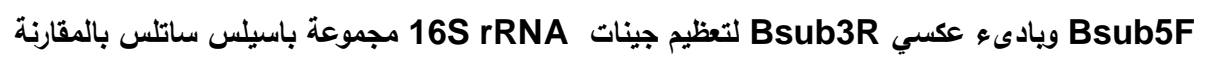
بسلالات مرجعية حيث تم توضيح بنجاح الثبة الواضح أو التطابق بين عزلات الباسيلس المعزولة فى هذه الاراسة مع مجموعة باسيلس ساتلس المرجعية. 